\title{
Flipped Learning in Science Education: Implications and Challenges
}

\section{Yousef Alrashed,}

Self-Development Department, Deanship of Preparatory Year and Supporting Studies,

\section{Imam Abdulrahman Bin}

Faisal University, P. O. Box: 1982, Dammam 34212, Saudi Arabia.

\section{ABSTRACT}

The popularity of learning approach such flipped learning have been growing widely over the world. In science education, flipped learning has been described as a useful tool in enhancing students' skills such learning, personal, social and cognitive. This study, therefore, investigate the contributions of flipped learning in science education and related fields as well as identify the implications and challenges facing flipped learning in science education. The results generally reported that flipped learning positively impacted science education environment. Additionally, recommendations were also highlighted.

Keywords:

Flipped learning, science, education, learning environment.

Article Received: 18 October 2020, Revised: 3 November 2020, Accepted: 24 December 2020

Literature highlighted several determinations of the individual success regardless their individual, social and academic factors (Jdaitawi, Almutawa, Musallam, \& Talafha, 2014; Al-Mutawa et al., 2014; Maya Panoraman \& Malek, 2011; Ismael et al., 2015; Jdaitawi et al., 2013). Reforms in higher education sector have led to the emphasis on the capability of the science educational model in equipping higher education students with the needed skills for the development of their future professional careers. Studying science entails different complex problem identification, problem investigation, formulation of hypotheses, collection of data, planning of methods, testing of hypotheses, obtaining results and reaching conclusions (Saidin et al., 2015; Meerah, 1998). According to Saidin et al. (2015), the participation of the students in the mentioned processes could enhance their critical thinking in every phase for optimum learning outcomes. Students often believe and perceive science subjects to be difficult which is why only a few of them choose to be in the science field, with some, later on, hindered by study issues including, disengagement and negative attitudes towards the courses (Howard, 2017). Cagande and Jugar (2018) mentioned that the reason behind this conundrum may be linked to the teaching approach that does not meet the time demands of students. In relation to this, the present adopted teaching methods have been shown to improve learning of general courses, but investigations about learning in science courses continue to present inconclusive and mixed findings (Kellems et al., 2020; Savelsbergh et al., 2016; Jdaitawi, 2020).

Educators have sought to change the learning environment by shifting the focus from instructor to student participation (Bansal et al., 2020). Presently, there are different learning methods that have been introduced to keep abreast with the dynamic ongoing societal changes and scientific and technological developments (Sojayapan \& Khlaisang, 2018). However, Mc Laughlin, et. (2016) stated that one of the more popular learning methods resulting from the developments in technology and pedagogy is flipped learning. In the world of learning, flipped learning is considered to be of valuable contribution towards teaching and learning, while at the same time enhancing successful learning outcomes of students (Jdaitawi, 2020; Rathner \& Schier, 2020; Akcayir \& Akcayir, 2018). In the context of science teaching-learning, the flipped-classroom approach has been proved to enhance student metacognition and collaborative learning (Van Vliet et al., 2015) and to improve student outcomes (Fatemah \& Jamebozorg, 2020; Gross et 
al., 2015) while others reported positive results of flipped learning in supporting students and engage them by increasing their motivation and managing cognitive load more effectively (Barrat et al., 2018; Abeysekera \& Dawson, 2014). 96

Flipped learning can be defined as the platform that deliver the passive teaching activities online (or through another medium), which the student accesses in his/her own time (homework), whereas active (student centered) learning activities are completed in the classroom (Rathner \& Schier, 2020; Akcayir \& Akcayir, 2018; Vliet, Winnips, \& Brouwer, 2015). Through flipped learning, the teacher is no longer the "speaker" on the podium; instead, the teacher becomes a coordinator for the students (He et al., 2019). Some scholars have described the nature of the flipped teaching mode as follows: by blending the strengths of internet-driven instruction outside the classroom (e.g., digital videos, self-regulated learning, online discussions) and face-to-face inside the classroom (e.g., collaborative study, applied problem-solving, instructor and peer engagement), the flipped learning model can effectively increase student engagement, improve student performance and strengthen the development of creative thinking (Eddy \& Hogan, 2014; McLaughlin et al., 2014; He et al., 2019; Persky, \& Pollack, 2010; Persky, \& Pollack, 2011). In the flipped learning context, students can not only selectively watch online videos based on their knowledge levels but also freely replay core and difficult content. In the classroom, teachers and students have sufficient time to conduct face-to-face discussions. Meanwhile, to enhance knowledge integration and application, students are asked to use in-class time for group discussion which can play an important role in improving students' understanding of the key points of the course (He et al., 2019; Vliet, Winnips, \& Brouwer, 2015).

Literature supported that by using flipped learning model, the students are engaged in more complex activities while they can obtain teachers feedback in a timely manner (Thai, De Wever, \& Valcke,
2017). Flipped learning enables teachers to encourage critical thinking in their students, building the capacity for lifelong learning and preparing future graduates for their work-place contexts (Akçayır \& Akçayır, 2018; O’Flaherty \& Phillips, 2015). The flipped classroom pedagogical approach encourages students to work independently to learn basic facts and concepts outside the classroom through varied methods, including reading, completing online education modules, and watching recorded lectures (Connor et al., 2019; Bergmann, Overmyer, \& Wille, 2018; Davies, Dean, \& Ball, 2013). In the current times, the students' interaction and engagement with learning activities have been enhanced by using flipped learning (Thai et al., 2017; He et al., 2019). Based on the flipped learning studies, flipped learning is able to promote teaching and learning results in terms of attitude, critical thinking, independent learning, interest, motivation, engagement, achievement and eventually, the students' satisfaction (Jdaitawi, 2020; Akcayir \& Akcayir, 2018; Connor et al., 2019; Eddy \& Hogan, 2014; McLaughlin et al., 2014; He et al., 2019; Yacout $\&$ Shoha, 2016). Evidence from literature shows that flipped learning strategy is capable of enhancing learning experiences and learning activities (Bansal, et al., 2020; Barrat et al., 2018; Helgevold \& Moen, 2015), and although such teaching approaches are clearly invaluable, studies dedicated to them are still lacking and what few there are reported mixed findings as to the intervention's effectiveness (Vliet et al., 2015; Jdaitawi, 2019; Gross et al., 2015; Adams et al., 2016; Brewer \& Movahedazarhouligh, 2018; Evans et al., 2019; Jdaitawi, 2020). Therefore, more studies are required to examine the flipped learning effectiveness in learning science courses in order to establish a systematic literature review on technology use in education fields (Esen \& Karagol, 2018; Chen et al., 2018; Cheng et al., 2018). Such systematic reviews are lacking despite their need to determine flipped learning trends effectiveness, particularly in science education (Lag \& Saele, 2019; Chen et al., 2018; 
Cheng et al., 2018). Thus, in the present study, literature on knowledge-based flipped learning interventions is extended through the analysis of science education-dedicated studies using different databases.

\section{Purpose of the Study}

Literature generally focused on the determinant effectiveness of flipped learning strategy in science courses, with studies presenting an extensive review of flipped learning factors remaining few and far between. In this regard, this study conducts a systematic literature review to identify the flipped learning status in the field of science education and it examines categories of analysis for this purpose and flipped learning advantages, limitations, effectiveness in the same context. The analysis of the different categories would stress on the emerging trends, opportunities, challenges and literature extension and visions towards the objectives and outcomes of its future usage. Flipped learning in science education is examined on the basis of the following research questions.

1. What are the skills achieved through flipped learning use in the science education?

2. What are the most education levels used in flipped learning science studies?

3. What are the advantages and challenges related to flipped learning in science studies?

\section{Methodology}

The study adopted Arksey and O'Malley (2005) and Kitchenham's (2004) four-tiered systematic review of studies involving the following phases: The study adopted Arksey and O'Malley (2005) and Kitchenham's (2004) four-tiered systematic review of studies involving the following phases: Identification of research questions - in the first phase, the trends in educational flipped learning studies conducted from 2015 to 2020 in were identified; flipped learning research dedicated to engineering education, 19 studies were selected from the databases and were deemed appropriate for the objectives of the study and the last phrase is required considering the research questions, which read, 1) What are the skills achieved through flipped learning use in the engineering education? (2) At which education level is flipped learning technology most frequently used for engineering students? and 3) What are the advantages and challenges related with flipped learning in engineering education?

\section{Results and Discussion}

Under this heading, the first question posed for the study states, "what are the skills achieved through flipped learning and in science courses? Accordingly, this study coded and tabulated the literature science education studies (refer to Table 1). The use of flipped learning in the science education field, according to Table 1, enhanced the science students' skills particularly their learning outcomes, their performance, attitudes, and both personal and cognitive skills (Matthew et al., 2019; Mabrouk \& Genedy, 2018; Sirota, 2017; Su \& Chen, 2018; Tomas, Evans \& Skamp, 2019; Cagande \& Jugar, 2018; Joseph, Rathner, Mark \& Schier, 2020). More specifically, the table lists 18 academic skills in most of the reviewed studies (10 studies, constituting 55.55\%), supporting the contention that flipped learning is effective in improving students' science learning. Flipped learning's contribution to cognitive skills was revealed by 4 studies $(22.25 \%)$ and occupied the second position on the list, while enhancement of personal skills was evidenced by 2 studies (11.10\%). Similarly, 2 studies (constituting $11.10 \%$ ) evidenced enhancement of social skills of students who were exposed to flipped learning approach - specifically revealing that the approach brought about students' interaction and collaborative learning, enabling their extensive engagement with their peers.

Other studies evidenced the positive influence of flipped learning on the students' various skills (e.g., Barral et al., 2019; Mabrouk \& Genedy, 2018; Nwosisi et al., 2016; Cgande et al., 2018; Mikael et al., 2018). This result may be attributed to the role of technology in the student's university life, particularly the flipped learning model that is extensively adopted for the teaching of science education. Students appear to perceive 
flipped learning model as an attractive learning strategy, holding their interests and encouraging their interaction with the contexts and their contribution to the learning sessions, understanding of content and achievement of optimum outcome (Mikael et al., 2018; Tutrang \& Schnke, 2017; Cagande \& Jugar, 2018). Moreover, this result supports the preference of flipped learning over other methods of teachinglearning, considering its positive effect on the skills of the students. Other advantages were mentioned by some of the examined studies specifically, Gopalan et al. (2017) revealed the experience of smooth knowledge-transfer and knowledge-sharing among learners with the assistance of media technology. According to the authors, the functions of multiple media contribute to the learning process and enhance long-term memory for storing information and knowledge. The result may also be linked to the use of scientific learning procedures in flipped learning in order to push achievements and understanding of abstract concepts to heights using practices and material engagement (Tutrang \& Schnke, 2017), which in turn, leads to skills gaining. According to Barral et al. (2019), flipping the classroom is a key strategy that effectively maximizes active learning methods in the classroom while providing individualized student's support. Also, flipped learning helps students' problem-solving engagement during classes (Tutrang \& Schnke, 2017).

Studies that examined non-learning outcomes in the form of social, cognitive and personal skills outcomes have been carried out adopting similar study designs from those that looked into learning outcomes. For instance, Cagande and Jugar (2018) conducted a comparison of students' readiness and motivation between flipped learning students and non-flipped learning students and found those exposed to flipped learning to have enhanced problem-solving skills. In the same line of study, Mikael et al. (2018) made use of two teaching models and revealed flipped learning to be capable of enhancing the engagement of students. Majority of similar studies showed that frequent utilization of flipped learning as a tool in science learning and as among the current technologies that can be integrated into learning to provide higher information and to extend access to knowledge (Tutrang \& Schnke, 2017; Abeysekera \& Dawson, 2015; Barral et al., 2019; Mabrouk \& Genedy, 2018; Nwosisi et al., 2016; Cgande et al., 2018; Mikael et al., 2018), while increasing the motivation and cognitive skills of students (Tutrang \& Schnke, 2017; Abeysekera \& Dawson, 2015).

Table 1: A Summary of the Studies Applying Flipped Learning in Science Education

\begin{tabular}{|c|c|c|c|}
\hline Skills & Authors & Variable & Finding \\
\hline \multirow[t]{4}{*}{ Academic } & $\begin{array}{l}\text { Tutrang \& } \\
\text { Schenke } \\
(2017)\end{array}$ & $\begin{array}{l}\text { Interest and study } \\
\text { skills }\end{array}$ & $\begin{array}{l}\text { Enhanced students' interest and } \\
\text { study skills }\end{array}$ \\
\hline & $\begin{array}{l}\text { Cronhjort, } \\
\text { Filipsson and } \\
\text { Weurlander } \\
\text { (2018) }\end{array}$ & $\begin{array}{l}\text { Engagement and } \\
\text { learning }\end{array}$ & $\begin{array}{l}\text { Improved students' engagement } \\
\text { and learning }\end{array}$ \\
\hline & Serry (2015) & $\begin{array}{l}\text { Active learning } \\
\text { and engagement }\end{array}$ & $\begin{array}{l}\text { Enhanced students learning and } \\
\text { their engagement }\end{array}$ \\
\hline & $\begin{array}{l}\text { Jafarkhani \& } \\
\text { Jamebozorg }\end{array}$ & $\begin{array}{l}\text { Academic } \\
\text { performance }\end{array}$ & $\begin{array}{l}\text { Cooperative flipped learning } \\
\text { enhanced students' academic }\end{array}$ \\
\hline
\end{tabular}




\begin{tabular}{|c|c|c|c|}
\hline & $(2020)$ & & achievement \\
\hline & Klann 2017 & $\begin{array}{l}\text { Students } \\
\text { performance }\end{array}$ & Improved students' performance \\
\hline & $\begin{array}{l}\text { Romero- } \\
\text { Garcia, } \\
\text { Buzon-Garcia } \\
\text { and Touron } \\
(2018)\end{array}$ & $\begin{array}{l}\text { Students } \\
\text { performance }\end{array}$ & $\begin{array}{l}\text { Flipped learning approach } \\
\text { impacted students' performance }\end{array}$ \\
\hline & $\begin{array}{l}\text { Gopalan } \\
(2019)\end{array}$ & $\begin{array}{l}\text { Performance and } \\
\text { perception }\end{array}$ & $\begin{array}{l}\text { Enhanced students' performance } \\
\text { and their perception }\end{array}$ \\
\hline & $\begin{array}{l}\text { Cagande \& } \\
\text { Jugar (2018) }\end{array}$ & $\begin{array}{l}\text { Motivation and } \\
\text { understanding }\end{array}$ & $\begin{array}{l}\text { Flipped learning enhanced } \\
\text { students learning and their } \\
\text { understanding }\end{array}$ \\
\hline & $\begin{array}{l}\text { Plazquez et } \\
\text { al. } 2019\end{array}$ & $\begin{array}{l}\text { Academic } \\
\text { performance }\end{array}$ & Improved students' performance \\
\hline & $\begin{array}{l}\text { Andrini, } \\
\text { Setyosari, } \\
\text { Zubaidah, \& } \\
\text { Ulfa (2017) }\end{array}$ & Learning outcomes & $\begin{array}{lll}\text { Improved } & \text { students learning } \\
\text { outcomes } & & \end{array}$ \\
\hline \multirow[t]{2}{*}{ Social } & Mikael 2018 & Engagement & Enhanced students' engagement \\
\hline & Jdaitawi 2019 & Learning outcomes & $\begin{array}{ll}\text { Enhanced students learning } \\
\text { outcomes and interest }\end{array}$ \\
\hline \multirow[t]{2}{*}{ Personal } & $\begin{array}{l}\text { Nwosisi, } \\
\text { Ferreira, } \\
\text { Rosenberg, \& } \\
\text { Walsh } \\
(2016) 2016\end{array}$ & $\begin{array}{l}\text { Students learning } \\
\text { skills }\end{array}$ & Improved Students study habits \\
\hline & $\begin{array}{l}\text { Mabrouk, H. } \\
\text { \& Genedy, G. } \\
(2018)\end{array}$ & $\begin{array}{l}\text { Work skills and } \\
\text { attitudes }\end{array}$ & $\begin{array}{l}\text { Flipped learning improved } \\
\text { students work and their attitudes }\end{array}$ \\
\hline \multirow[t]{4}{*}{ Cognitive } & Su 2018 & $\begin{array}{l}\text { Learning } \\
\text { motivation and } \\
\text { engagement }\end{array}$ & $\begin{array}{l}\text { Improved students' motivation } \\
\text { and engagement }\end{array}$ \\
\hline & $\begin{array}{l}\text { Chung and } \\
\text { Lee (2018) }\end{array}$ & $\begin{array}{l}\text { Motivation and } \\
\text { attitude }\end{array}$ & $\begin{array}{l}\text { Enhanced students' motivation } \\
\text { and attitudes }\end{array}$ \\
\hline & $\begin{array}{l}\text { Barral, } \\
\text { Pastores \& } \\
\text { Simmons } \\
(2018)\end{array}$ & $\begin{array}{l}\text { Learning } \\
\text { environment }\end{array}$ & $\begin{array}{l}\text { Flipped learning enhanced } \\
\text { students learning }\end{array}$ \\
\hline & $\begin{array}{l}\text { Jdaitawi } \\
(2020)\end{array}$ & Positive Emotions & $\begin{array}{l}\text { Flipped learning } \\
\text { positive emotions }\end{array}$ \\
\hline
\end{tabular}

With regards to the second research question that asks the education level that is mostly sampled in science education when it comes to flipped learning, Table 2 shows that majority of the studies were conducted among bachelor level students (17 studies, $89.50 \%$ ), followed by master 
level students (2 studies, 10.50\%) and none among $\mathrm{PhD}$ level students in the science field. The flipped learning approach mainly motivates the students, clarifies topics to them and improves their experiences and engagement in learning. In fact, majority of the teaching-learning sessions in flipped learning had their basis on practical instruction and thus, computer-assisted instruction is a method that can effectively be used in higher education. Moreover, masters and $\mathrm{PhD}$ sample students in flipped learning studies have yet to be extended due to their scarcity in literature - such scarcity may be related to their hour loads and maturity level of education. Contrastingly, those taking their bachelor's degree need to be encouraged and to be taught how to be selfdirected as learners in comparison to their higherlevel counterparts. Therefore, this study makes a call to examine the effectiveness of flipped learning model among master and $\mathrm{PhD}$ students in science education field.

Table 2: A summary of the Sample used in flipped learning for Science Education

\begin{tabular}{|l|l|l|}
\hline Sample & No. & Percentage \\
\hline Bachelor & 17 & $89.50 \%$ \\
\hline Master & 2 & $10.50 \%$ \\
\hline PhD & 0 & 00 \\
\hline
\end{tabular}

The study's third question is concerned with the advantages, limitations and challenges of flipped learning in science education. In this regard, flipped learning usage in science education has been evidenced to lead to enhance learning skills, learning outcomes, performance, attitudes, as well as enhanced personal and cognitive skills of students (see Matthew et al., 2019; Mabrouk \& Genedy, 2018; Sirota, 2017; Su \& Chen, 2018; Tomas, Evans \& Skamp, 2019; Cagande \& Jugar, 2018; Joseph, Rathner, Mark \& Schier, 2020). To begin with, flipped learning advantages highlighted by Tutrang and Schnke (2017) included facilitating of experimentation to support learning and changing study practices of students. In a study conducted by Barral et al. (2019), the author stated that flipped classroom is an effective strategy that increases the active learning approaches within the classroom, while at the same time providing individualized support to students. Flipped learning also helps students to tackle problem-solving activities in their classes (Tutrang \& Schnke, 2017).

In addition to the above studies, Fridhi et al. (2018) and Lin et al. (2016) evidenced the improvement of the students' learning motivation, their positive interest, behaviors, learning outcomes and their cognitive skills - this result was also supported by other prior studies (Matthew et al., 2019; Mabrouk \& Genedy, 2018; Sirota, 2017; Su \& Chen, 2018; Tomas, Evans \& Skamp, 2019; Cagande \& Jugar, 2018; Joseph, Rathner, Mark \& Schier, 2020). This result may be because of the flipped learning model is attractive to science students (Cagande \& Jugar, 2018), which explains their positive response towards it. Mikael et al. (2018) revealed that flipped learning enhances social skills of students along with their motivation, while Tutrang and Schnke (2017), Abeysekera and Dawson (2015) and Fridhi et al. (2018) stated that peer and teacher interactions in flipped learning motivates the students, heightens their engagement and enhances their skills development. Lastly, flipped learning boosts the personal skills, social interactions and motivation of students (Matthew et al., 2019; Christopher et al., 2016; Su \& Chen, 2018).

\section{Conclusion}

The extensive use of flipped learning only began in the last few decades in providing science information and curricula to science students. In this study, the focus is laid on the effectiveness of flipped learning in affecting the outcomes of 
students in science courses. The study carried out a systematic review to determine the use of flipped learning strategy from the perspective of students, highlighting the strengths and weaknesses of approaches, and providing data to comprehend the way flipped learning can minimize the different limitations and challenges that students of science courses face when it comes to using flipped learning. The literature review on the use of flipped learning technique showed a total of 19 implementations with the studies agreeing on the positive role of flipped learning technique in science courses in different levels (bachelor, master, and $\mathrm{PhD}$ level students). The studies also showed different technologies utilized including computer, laptop, and mobile devices. They revealed that flipped learning mode was successful in enhancing the student's skills and positive learning outcomes.

Limitations and suggestions

This study has some limitations like other studies, in which the majority of the studies did not examine the influence of students' characteristics, which needs to be examined in future studies. Majority of them also used small-sized samples of participants, and thus, future studies should consider bigger sized samples to validate the findings. Another limitation relates to data collection methods, which future studies should consider, so that they can adopt other approaches. This systematic review presented information concerning ideas and solutions as to how science achievement among students can be improved through flipped learning strategy implemented.

\section{Reference}

[1] Abeysekera, L., \& Dawson, P. (2014). Motivation and cognitive load in the flipped classroom: Definition, rationale and a call for research. Higher Education Research \& Development, $\quad 34(1), \quad$ 1-14. https://doi.org/10.1080/ 07294360.2014 .934336$.

[2] Al-Mutawa, A., Jdaitawi, M., Saleh, W., \& Awwad, A. (2014). Psychological strain among academic staff in Eastern Saudi
Arabia. Paper presented at the Social Science Conference, Malaysia.

[3] Arksey, H. \& O’Malley, L. (2005). Scoping studies: towards a methodological framework. International Journal of Social Research Methodology, 8(1), 19-32. http://doi.org/10.1080/13645570320001196 16.

[4] Aycicek, B., \& Yelken, T. (2018). The effect of flipped classroom model on student's classroom engagement in teaching English. International Journal of Instruction, 11(2), 385-398.

[5] Barral, A., Pastores, V., \& Simmons, R. (2018). Student learning in an accelerated introductory biology course is significantly enhanced by a flipped learning environment. CBE-Life Science Education, 17:ar38, 1-9. Doi 10.1187/cbe.17-07-0129.

[6] Brewer, R. \& Movahedazarhouligh, S. (2019). Flipped learning in flipped classrooms: A new pathway to prepare future special educators. Journal of Science Teacher Education. Doi: 10.1080/21532974.2019.1619110.

[7] Bansal, S., Bansal, M., Ahmad, K., \& Pandey, J. (2020). Effects of a flipped classroom approach on learning outcomes of higher and lower performing medical students: A new insight. Advances in Educational Research and Evaluation, 1(1). Doi:10.25082/AERE.2020.01.005

[8] Bergmann, J. \& Sams, A. (2018). Flip your classroom: reach every student in every class every day. International Society for Technology in Education. 112 p. Available from: https:// www.iste.org/resources/product?ID=2285.

[9] Barrat, A., Pastores, V., \& Simmons, R. (2018). Student learning in an accelerated introductory biology course is significantly enhanced by a flipped learning environment. CBE-Life Science Education, 17:ar38, 1-9. Doi 10.1187/cbe.17-07-0129. 
[10] Bansal, S., Bansal, M., Ahmad, K., \& Pandey, J. (2020). Effects of a flipped classroom approach on learning outcomes of higher and lower performing medical students: A new insight. Advances in Educational Research and Evaluation, 1(1). Doi:10.25082/AERE.2020.01.005

[11] Cagande, J. \& Jugar, R. (2018). The flipped classroom and college physics students motivation and understanding of kinematics graphs. Issues in Education Research, 28(2), pp. 288-307. Available through: ERIC website.

[12] Chen, K., Monrouxe, L., Lu, Y., Jenq, C., Chang, Y., Chang, Y., \& Chai, P. (2018). Academic outcomes of flipped classroom learning: A meta-analysis. Medical Education, 52, 910-924. doi:10.1111/medu.13616.

[13] Cheng, L., Ritzhaupt, A. D., \& Antonenko, P. (2018). Effects of the flipped classroom instructional strategy on students' learning outcomes: A meta-analysis. Educational Technology Research \& Development, 67, 793-824. doi:10.1007/s11423-018-96337 .

[14] Connor, E., Fried, J., McNulty, N., \& Shah, P. (2019). Flipping radiology education right side up. Academic Radiology, 23(7). Doi: 10.1016/j.acra.2016.02.001.

[15] Davies, R., Dean, D., \& Ball, N. (2013). Flipping the classroom and instructional technology integration in a college-level information systems spreadsheet course. Educational Technology Research and Development, 61(563-580). http://doi.org/10.1007/s11423-013-9305-6.

[16] Eddy, S. L., Converse, M., \& Wenderoth, M. P. (2015). PORTAAL: A classroom observation tool assessing evidence-based teaching practices for active learning in large science, technology, engineering, and mathematics classes. CBE-Life Sciences Education, 14(2), ar23. https://doi.org/ 10.1187/cbe.14-06-0095.
[17] Esen, E. \& Karagol, I. (2018). The effect of flipped learning approach on academic achievement: A meta analysis study. Egitim Fakultesi Dergisi. DOI: 10.16986/HUJE.2018046755.

[18] Evans, L., Vanden Bosch, M. L., Harrington, S., Schoofs, N., Coviak, C. (2019). Flipping the classroom in health care higher education: A systematic review. Nurse Educator, $\quad 44,74-78$. doi:10.1097/NNE.0000000000000554.

[19] Fatemeh, J., \& Jamebozorg, Z. (2019). Comparing cooperative flipped learning with individuals flipped learning in a biochemistry course. Journal of Medicine and Life, 13(3), 399-403. Doi: 10.25122/jml2019-0149.

[20] Gopalan, C. \& Klann, M. (2017). The effect of flipped teaching combined with modified team-based learning on student performance in physiology. Advances Physiology Education, 41: 363-367. Doi: 10.1152/advan.00179.2016.

[21] Gross, D., Pietri, E. S., Anderson, G., Moyano-Camihort, K., \& Graham, M. J. (2015). Increased preclass preparation underlies student outcome improvement in the flipped classroom. CBE.Life Sciences Education, $\quad 14(4), \quad 1-8$. http://doi.org/10.1187/cbe.15-02-0040.

[22] He Y, Lu J, Huang H, He S, Ma N, Sha Z, et al. (2019) The effects of flipped classrooms on undergraduate pharmaceutical marketing learning: A clustered randomized controlled study. PLoS ONE 14(4), e0214624. https://doi.org/10.1371/journal.pone.021462 4.

[23] Helgevold, N., \& Moen, V. (2015). The use of flipped classrooms to stimulate students' participations in an academic course in Initial Teacher Education. Nordic Journal of Digital Literacy, 10(1), 29-42.

[24] Howard, S. (2017). Scientific inquiry: Considering continuity, progression ans reasons to focus on primary and secondary 
transition in England. Science Teacher Education, 79.

[25] Ishak, N., Jdaitawi, M., Ibrahim, Y., \& Mustafa, F. (2011). Moderating effect of gender and age on the relationship between emotional intelligence with social and academic adjustment among first year university students. International Journal of Psychological Studies, 3(1), 78-89.

[26] Ismael, A., Jdaitawi, M., \& Talafha, F. (2015). Towards a better investment of university students in light of the twentieth century challenges. International Educational Studies, 8(6), 113-123.

[27] Jdaitawi， M. (2020). Does flipped learning promote positive emotions in science education? A comparison between traditional and flipped classroom approaches. The Electronic Journal of e-Learning, 18(6), 516524.

[28] Jdaitawi, M. (2020). The effect of using problem-based learning upon students emotions towards larning and levels of communication skills in three different disciplines. Croatian Journal of Education, 22(1), 207-240. http://doi.org/10.15516/cje.v22i13215.

[29] Jdaitawi, M., Al-Mutawa, A., Musallam, F., \& Talafha, F. (2014). Stress and psychological strain among university lecturers in Saudi Arabia. Paper presented at the Global Conference on Business and Finance, 9(1).

[30] Jdaitawi, M. et al. (2013). Students perspectives on university experiences; the role of protective factors in students lives. International Education Studies, 6(7), 239246.

[31] Jdaitawi, M. (2019). The effects of flipped classroom strategy on students learning outcomes. International Journal of Instruction, 12(3), pp. 665-680. doi:10.29333/iji.2019.12340a.

[32] Kellems, R., Cacciatore, G., \& Osborne, K. (2019). Using an augmented reality-based teaching strategy to teach mathematics to secondary students with disabilities. Career Development and Transition for Exceptional Individuals. http://doi: 10.1177/2165143418822800.

[33] Kitchenham, B. (2004). Procedures for performing systematic reviews. http://citeseerx.ist.psu.edu/viewdoc/summar y?doi=10.1.1.122.3308.

[34] Lag, T. \& Saele, R. (2019). Does the flipped classroom improve student learning and satisfaction? A systematic review and metaanalysis. AERA Open. http://doi.org/10.1177/2332858419870489.

[35] Malek, J. (2015). Social connectedness, academic, non-academic behaviors related to self-regulation among unievristy stduents in Saudi Arabia. Interantional Education Studies, 8(2), 84-100.

[36] Malek, J. (2019). The effect of flipped classroom strategy on students learning outcomes. International Journal of Instruction, 12(3), 665-680.

[37] Maya Panorama., \& Malek, J. (2011). Relationship between emotional intelligence and work-family conflict of university staff in Indonesia. Paper presented at the International Conference on Social Science, Economics and Arts, 14-15 January, Malaysia.

[38] McLaughlin, J., White, P., Khanova, J. \& Yuriev, E., 2016. Flipped classroom implementation: a case report of two higher education institutions in the United States and Australia. Computers in the Schools, 33(1), pp. 24-37. doi: 10.1080/07380569.2016.1137734.

[39] Meerah, T. S. (1998). Dampak Penyelidikan Pembelajaran Sains Terhadap Perubahan Kurikulum. UKM Bangi, Selangor: Penerbit Universiti Kebangsaan Malaysia.

[40] Mikael, C., Filipsson, L., \& Maria, W. (2017). Improved engagement and learning in flipped-classroom calculus. Teaching Mathematics and its Applications, 37, 113121. Doi: 10.1093/teamat/hrx007.

[41] Mabrouk, H. \& Genedy, G. (2018). Effectiveness of flipped classroom using the 
blackboard system in developing art work skills and attitudes of faculty of education female students at Jouf university toward the use of practical skills. JRCIET, 4(3), 141161.

[42] Matthew, S. M., Schoenfeld-Tacher, R. M., Danielson, J. A. , \& Warman, S. M. (2019). Flipped Classroom Use in Veterinary Education: A multinational survey of faculty experiences. Journal of Veterinary Medical Education, $\quad 46(1), \quad 97-107$. https://doi.org/10.3138/jvme.0517-058r1.

[43] Nielsen, K. (2020). Students video viewing habits during a flipped classroom course in engineering mathematics. Research in Learning Technology, 28, 2404. http://dx.doi.org/10.25304/rtl.v28.2404.

[44] Nwosisi, C., Ferreira, A., Rosenberg, W., \& Walsh, K. (2016). A study of the flipped classroom and its effectiveness in flipping thirty percent of the course content. International Journal of Information and Education Technology, 6(5).

[45] O'Flaherty, J. \& Phillips, C. (2015). The use of flipped classrooms in higher education: A scoping review. Internet and Higher Education, 25, 85-95.

[46] Persky, A. \& Pollack, G. (2011). A modified team-based learning physiology course. Am J Pharm Educ, 75(10).

[47] Persky, A. \& Pollack, G. (2010). Transforming a large-class lecture course to a smaller-group interactive course. American Journal of Pharmaceutical Education, 74(9), 170.

[48] Peterson, D. J. (2016). The flipped classroom improves student achievement and course satisfaction in a statistics course: A quasi-experimental study. Teaching of Psychology,43(1), 10-15.

[49] Rathner, J. \& Schier, M. (2020). The impact of flipped classroom andragogy on student assessment performance and perception of learning experience in two advanced physiology subjects. Advances in Physiology
Education, 44(1).

Hhtp://doi.org/10.1152/advan.00125.2019.

[50] Saidin, N., Halim, N., \& Yahaya, N. (2015). A review of research on augmented reality in education: Advantages and applications. International Education Studies, 8(13). Doi: 10.5539/ies.v8n13p1.

[51] Savelsbergh, E., Prins, G., Rietbergen, C., Fechner, S., Vaessen, B., Draijer, J., \& Bakker, A. (2016). Effects of innovative science and mathematics teaching on student attitudes and achievement: A meta-analytic study. Educational Research Review, 19, 158-172.

http://doi.10.1016/j.edurev.2016.07.003.

[52] Sojayapan, C., and Khlaisang, J., 2018. The effect of a flipped classroom with online group investigation on students team learning ability. Kasetsart Journal of Social Science. doi:10.1016/j.kjss.2018.02.003.

[53] Sirota, N. (2017). Nursing students academic performance with flipped classroom pedagogy in nursing pharmacology. Unpublished Doctoral Dissertation, Alabama University.

[54] Su, C. \& Chen, C. (2018). Investigating the effects of flipped learning, student question generation, and instant response technologies on students learning, motivation, attitudes, and engagement: A structural equation modeling. EURASIA Journal of Mathematics, Science and Technology Education, 14(6), 2453-2466. http://doi.org/10.29333/ejmste/89938.

[55] Thai, N., Wever, B., \& Valcke, M. (2017). The impact of a flipped classroom design on learning performance in higher education: Looking for the best blend of lectures and guiding questions with feedback. Computer \& Education. Doi: 10.1016/j.compedu.218.01.003.

[56] Tomas, L., Evans, N., \& Skamp, K. (2019). Are first year students ready for a flipped classroom? A case for a flipped learning continuum. International Journal of Educational Technology in Higher 5706 
Education, $16(5)$.

http://doi.org/10.1186/s41239-019-0135-4.

[57] Tutrang, T. \& Schenke, K. (2017). Can flipped the classroom work? Evidence from undergraduate chemistry. International Journal of Teaching and Learning in Higher Education, 29(3), 421-435.

[58] Vliet, E., Winnips, J., \& Brouwer, N. (2015). Flipped-class pedagogy enhance student metacognition and collaborative-learning strategies in Higher education but effect does not persist. CBE Life Science Education, 14(3), 1-10. 10.1187/cbe.14-090141.

[59] Wells, M. \& Holland, C. (2015). Flipping learning: Challenges in deploying online resources to flipped learning in higher education. Advance in Educational Technologies and Instructional Design (AETID). DOI: 10.4018/978-1-4666-96808.ch001.

[60] Yacout, D. (2016). Nursing students perceptions towards flipped classroom educational strategy. Journal of American Science, $\quad$ 12(2), 62-75. Doi:10.7537/marsjas 12021607. 